\title{
BMP-9 expression in human traumatic heterotopic ossification: a case report
}

\author{
Guillaume Grenier ${ }^{1,2}$, Élisabeth Leblanc ${ }^{3,4}$, Nathalie Faucheux ${ }^{1,5}$, Dominique Lauzier ${ }^{3}$, Peter Kloen ${ }^{6}$ \\ and Reggie C Hamdy ${ }^{3,4^{*}}$
}

\begin{abstract}
Background: Heterotopic ossification ( $\mathrm{HO})$ is defined as the abnormal formation of mature bone in soft tissue, notably skeletal muscle. The morbidity of $\mathrm{HO}$ in polytraumatized patients impacts the functional outcome, impairs rehabilitation, and increases costs due to subsequent surgical interventions.

Case presentation: We present the case of a 34-year-old African male who developed severe $\mathrm{HO}$ around his right hip 11 days after a major trauma. Immunohistochemical analyses of resected tissue revealed that several BMPs were expressed in the $\mathrm{HO}$, including highly osteogenic BMP-9.

Conclusions: To the best of our knowledge, this is the first report of local BMP expression, notably BMP-9, in traumatic $\mathrm{HO}$, and suggests that BMP-9, possibly through mrSCs, can contribute to $\mathrm{HO}$ formation in soft tissues when a suitable microenvironment is present.
\end{abstract}

Keywords: BMP-9, Traumatic heterotopic ossification, Muscle resident stromal cells

\section{Background}

Heterotopic ossification (HO) involves ectopic bone formation in soft tissues such as muscles and is often associated with trauma [1]. While the etiology of $\mathrm{HO}$ has been classified as neurogenic, traumatic, and hereditary, the exact pathophysiology of traumatic $\mathrm{HO}$ remains unknown. However, several critical factors such as progenitor cell populations, inductive factors, and a permissive environment may contribute to $\mathrm{HO}[2,3]$.

BMPs play a critical role in the osteoblastic commitment of mesenchymal cells and the induction of osteoblastic activity $[4,5]$, and are potential candidates as inductive $\mathrm{HO}$ factors. BMPs are members of the transforming growth factor-beta (TGF- $\beta$ ) family [6]. More than 20 BMPs have been described to date, but experimental evidence indicates that only BMP-2, $-6,-7$, and -9 can induce osteogenesis, BMP-9 being one of the most potent osteogenic BMPs $[7,8]$. In addition, we recently reported that BMP-9 only induces $\mathrm{HO}$ in damaged muscle in a murine model [9].

\footnotetext{
*Correspondence: rhamdy@shriners.mcgill.ca

${ }^{3}$ Shriners Hospital for Children, 1529 Cedar Avenue, Montreal, QC H3G 1A6,

Canada

${ }^{4}$ Department of Surgery, Orthopedic Surgery Division, McGill University,

Montreal, QC, Canada

Full list of author information is available at the end of the article
}

Despite the fact that BMP-9 transcripts are barely detectable in human skeletal muscle [10], no studies have examined the expression of BMPs, including BMP-9, in human HO.

The BMP pathway is regulated by a negative feedback mechanism involving extracellular inhibitors such as noggin, chordin, and gremlin, membrane pseudo-receptors such as BAMBI, and the intracellular inhibitors Smad-6 and Smad-7 [11,12]. Based on studies by our group and others on the role of BMPs in normal and pathologic bone healing [13-17], we hypothesized that the balance between BMPs and their inhibitors may play a key role in the development of traumatic human HO.

In the present report, we describe the case of a patient with severe lower extremity trauma who developed HO. We determined the locations of BMPs, extracellular BMP antagonists, and BMP receptor BMPR1a by immunohistochemical staining. We propose a mechanism to explain the pathogenesis of trauma-associated $\mathrm{HO}$ and provide a novel perspective on the involvement of members of the BMP family.

\section{Case presentation}

A 34 year-old African male was brought to the emergency department after jumping from the seventh floor of an apartment building during a police raid. Physical and 
Table 1 Primary and secondary antibodies used for the immunohistochemical staining procedure

\begin{tabular}{lcc}
\hline Primary antibody & Catalog number & Type \\
\hline BMP-2 & sc-6895 & Goat pAb \\
BMP-7 & sc-34766 & Rabbit pAb \\
BMP-9 & sc-130703 & Rabbit pAb \\
Chordin & sc-28964 & Rabbit pAb \\
Gremlin & sc-28873 & Rabbit pAb \\
Noggin & sc-25656 & Rabbit pAb \\
BAMBI & sc-100681 & Mouse mAb \\
BMPR1a & sc-5676 & Goat pAb \\
Secondary antibody & & \\
Biotinylated horse anti-goat lgG & BA-9500 & \\
Biotinylated goat anti-rabbit lgG & BA-1000 & \\
Biotinylated goat anti-mouse lgG & BA-9200 & \\
\hline
\end{tabular}

radiological examinations revealed a $\mathrm{C} 1$ fracture, a carpal dislocation, and a T-type fracture of the right acetabulum.

On the day of admission (Day 0), an open reduction and internal fixation (ORIF) of the acetabular fracture was performed using a standard Kocher-Langenbeck approach associated with a trochanteric flip [18].

A revision for suboptimal reduction was performed on Day 10 , followed by a second stage ORIF the next day using an ilioinguinal approach [19]. During the revision surgery, a mass of heterotopic bone was resected and sent for analysis. The patient did not receive NSAIDs or radiotherapy preoperatively. Clinical and radiological evaluations were performed for three and a half months postoperatively.

\section{Methods}

Tissue specimen

The tissue specimen harvested during the second surgery (Day 11) was processed for immunohistochemical and histological analyses.
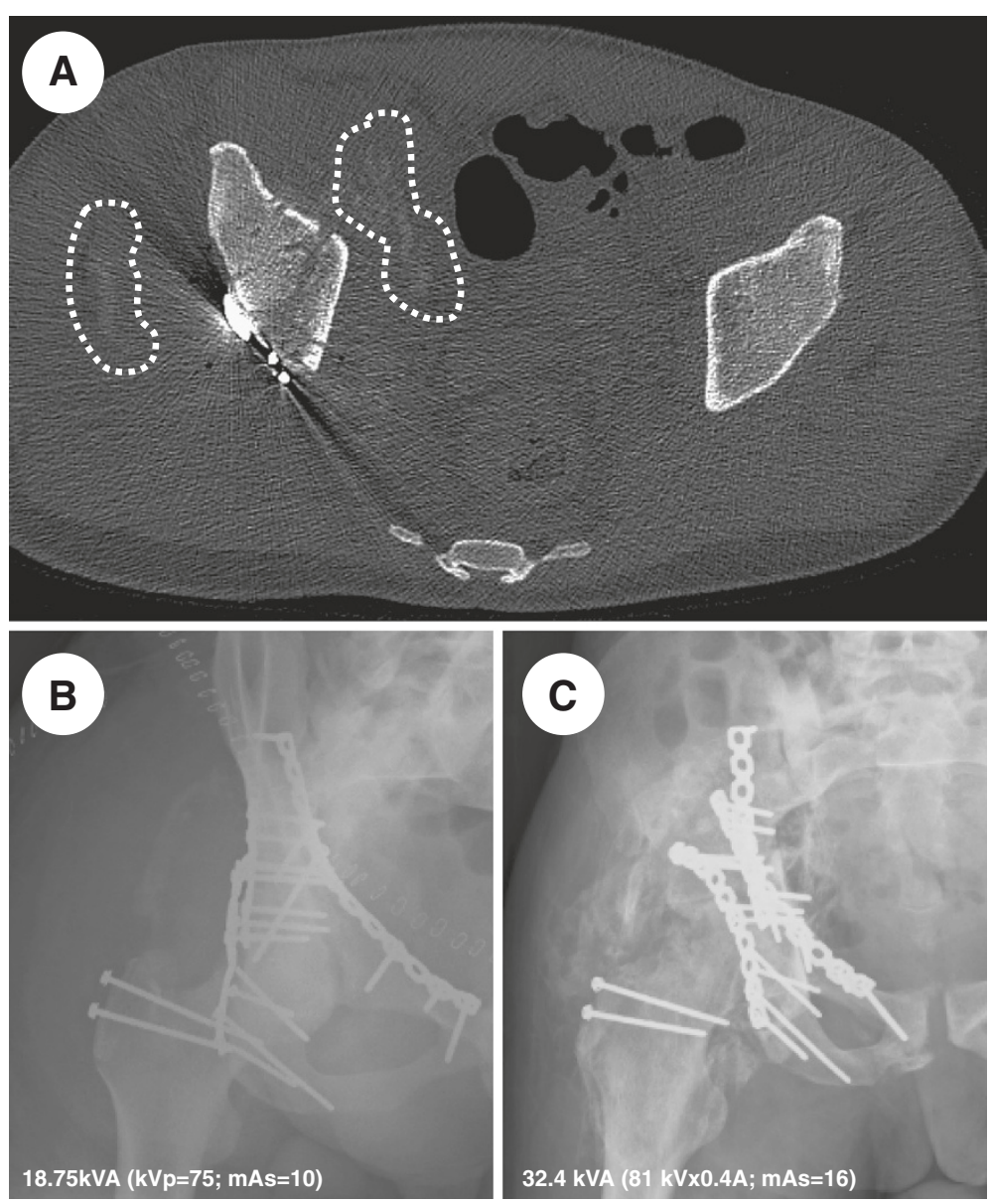

Figure 1 Early and late radiological evidence of heterotopic ossification around the right hip. (A) Axial computerized tomography (CT) scan cut of the acetabular region 11 days post-trauma. Note the denser soft tissues (encircled) surrounding the right fractured acetabulum. Radiographic AP view of the right hip at 14 days; (B) and three and a half months; (C) post-trauma. Note the progression of calcified soft tissues medially and laterally within the abductor muscles. 


\section{Histology and immunohistochemistry}

The sample was fixed in buffered formalin overnight, decalcified in 10\% EDTA ( $\mathrm{pH}$ 7.2) for three weeks, embedded in paraffin, and sectioned using a Leica RM 2255 microtome (Leica Microsystems, Richmond Hill, ON, Canada). Following deparaffinization and hydration, the tissue sections were stained with Goldner's trichrome to visualize nuclei (blue-gray), cartilage (redpurple), osteoid (orange-red), and mineralized bone (green).

The immunohistochemistry was performed as described previously [13-15]. Commercially available goat and rabbit pAbs and a mouse mAb $(1: 100$ in $1 \%$ goat or $1 \%$ horse serum) were used to detect BMP-2, BMP-7, BMP-9, noggin, gremlin, BMPR1a, and BAMBI (Santa Cruz Biotechnology Inc., Santa Cruz, CA, USA). A list of the antibodies is given in Table 1.

\section{Grading of the immunostained sections}

Immunohistochemical staining of cellular and extracellular proteins has been used in mandibular [20], long bone distraction osteogenesis [21-24], and bone healing [13-15] studies. We employed this technique to semiquantitatively evaluate our results based on the percentage of positively stained cells using the following grading scheme:,$+ 25 \%$ of the cells stained positively for the protein of interest;,++ 25 to $50 \%$ of the cells stained positively;,+++ 50 to $75 \%$ of the cells stained positively; ++++ , more than $75 \%$ of the cells stained positively; - , no cells stained positively.

\section{Results}

Radiological and clinical follow-up

Computerized tomography $(\mathrm{CT})$ imaging prior to the second surgery (Day 11) revealed the presence of dense ectopic tissue in the musculature (Figure 1A). A post-ORIF radiological examination (Day 14) revealed adequate reduction/fixation as well as the presence of dense tissue in the abductor muscles (Figure 1B). Three and a half months later, a repeat antero-posterior (AP) radiograph of the pelvis revealed a healed fracture and a Brooker radiologic stage III-IV HO (Figure 1C) [25]. While follow-up with this patient was limited, clinical notes indicated that he had a stiff hip gait.

\section{Macroscopic and microscopic tissue organization}

The resected tissue had a macroscopic rubbery texture on the day of the revision surgery (Day 11). A histological examination showed that the tissue was composed mainly of mature bone and cartilage (Figure 2). Adipocytes organized in a bone marrow-like structure in the ectopic bone were also observed. The structure was well vascularized, as previously reported $[9,26]$. We also observed muscle fiber remnants intertwined with the tissue.

\section{Expression of BMPs, BMP receptors and their antagonists} Chondrocytes stained fairly strongly for BMP-2 (Figure 3). Interestingly, while BMP-9 was expressed in various cell types, the most intense staining was observed in osteoblasts followed by endothelial cells (Figure 3). The receptor antagonist BAMBI was mainly expressed in osteoblasts while BMPR1a was mainly expressed in chondrocytes.
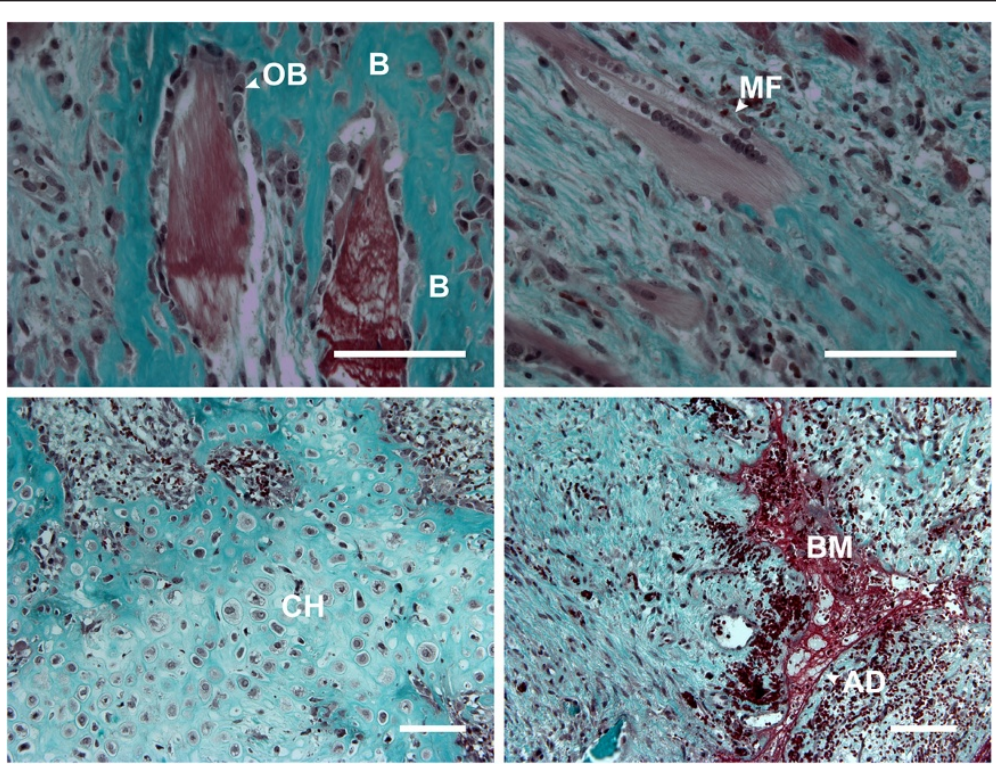

Figure 2 Resected heterotopic ossification ( $\mathrm{HO}$ ) tissue with endochondral ossification. Micrograph of a section of resected tissue stained with Goldner's trichrome. AD, adipocyte; B, bone; BM, bone marrow; CH, chondrocyte; MF, myofiber; OB, osteoblast. Scale bar $=100 \mu \mathrm{m}$. 

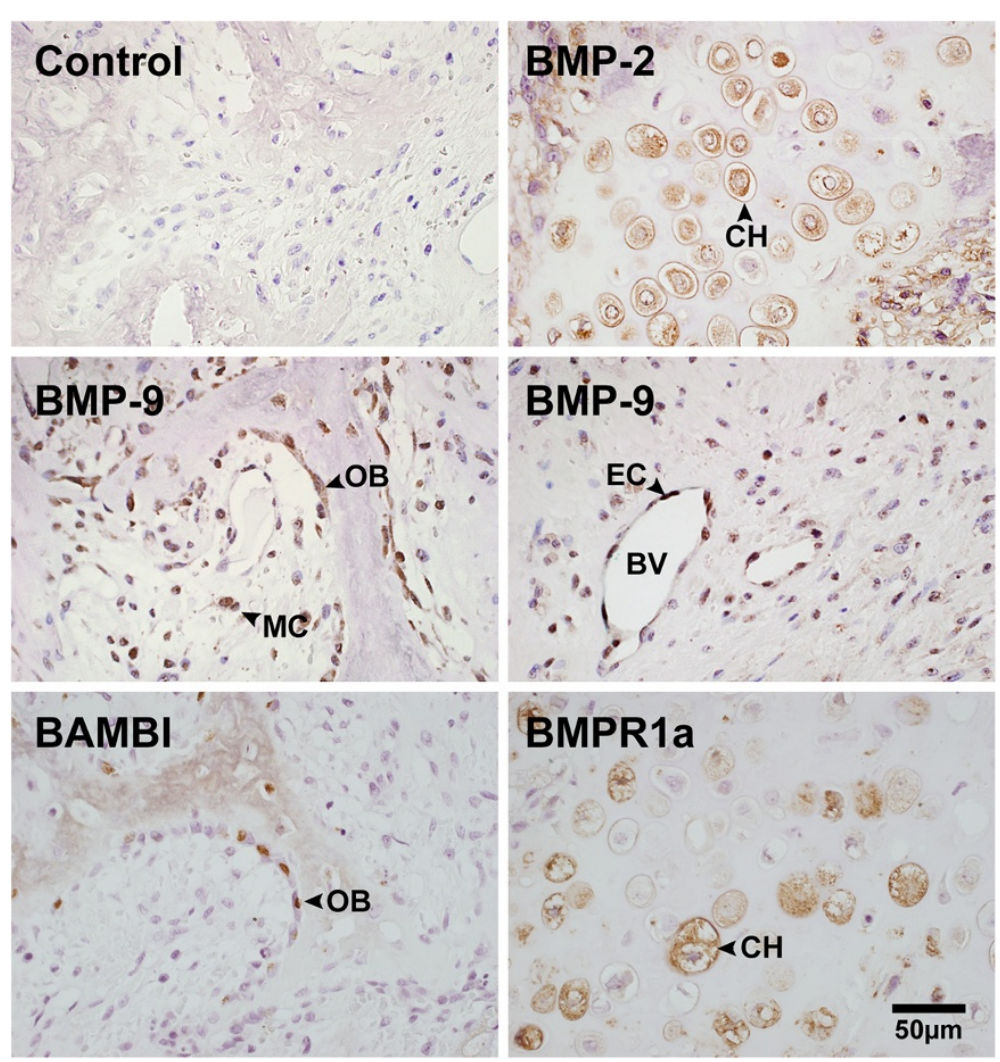

Figure 3 Immunostaining of resected heterotopic ossification (HO) tissue. Micrographs of resected tissue immunostained for various proteins in the BMP pathway. The control shows background staining. BV, blood vessel; $\mathrm{CH}$, chondrocyte; EC, endothelial cell. MC, mesenchymal cell; OB, osteoblast.

Noggin, chordin, and gremlin, the extracellular antagonists of BMP-2 and BMP-7, were mainly observed in chondrocytes and mesenchymal cells. See Table 2 for a summary of the immunostaining results.

\section{Discussion}

In the present case report, we describe for the first time the expression patterns of several BMPs as well as BMP receptors and their antagonists in traumatic HO. We found that BMP expression patterns were cell type-dependent, with chondrocytes expressing the highest levels of BMP-2, mesenchymal cells the highest levels of BMP-7, and osteoblasts and endothelial cells the highest levels of BMP-9. This is the first time that BMP-9 has been shown to be expressed in human ectopic bone. This is an important finding since it has been previously reported that BMP-9 is the most osteogenic BMP both in vitro and in vivo $[7,8]$. Unlike BMP-2, which can induce $\mathrm{HO}$ in undamaged skeletal muscle, BMP-9 induces $\mathrm{HO}$ only in damaged muscle [9]. While BMP-2 and BMP-9 share the same pathway, they do not appear to be functionally equivalent in terms of inducing heterotopic bone in skeletal muscle. Two main factors seem to be responsible for this difference and make the involvement of BMP-9 in HO more plausible. The microenvironment of cells in damaged muscle is more permissive to the development of HO [9,27]. Since BMP-9 is involved in angiogenesis [28] and participates in endothelial cell proliferation, severe muscle trauma may promote higher local expression of BMP-9 and, as such, HO. In addition, despite the fact that BMP inhibitors were expressed in the sample we analyzed, osteogenesis still

Table 2 Immunolocalization of BMP receptors, agonists, and antagonists

\begin{tabular}{lcccc}
\hline Antibody & OB & CH & FB & MC \\
\hline BMP-2 & + & ++++ & - & ++ \\
BMP-7 & - & + & - & +++ \\
BMP-9 & ++ & + & - & + \\
BMPR1a & - & ++++ & - & - \\
Chordin & - & ++ & + & ++++ \\
Gremlin & - & ++++ & + & +++ \\
Noggin & - & ++++ & + & ++ \\
BAMBI & ++ & - & - & - \\
\hline
\end{tabular}

$\mathrm{CH}$ : chondrocytes; FB: fibroblasts; MC: mesenchymal cells; OB: osteoblasts. 


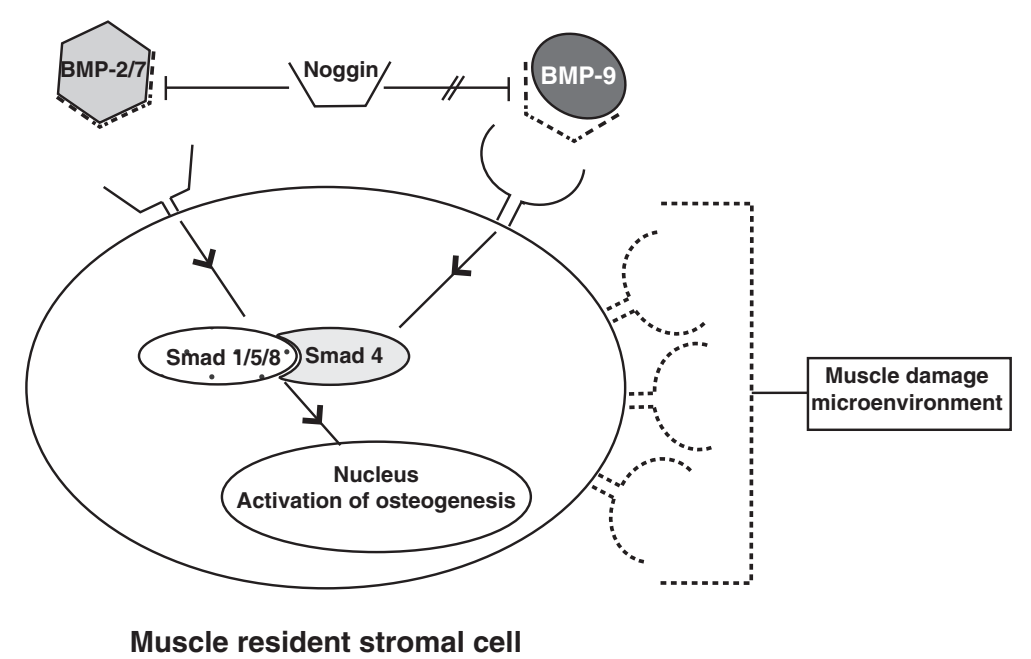

Figure 4 Diagram illustrating that BMP-9 may play a pivotal role in heterotopic ossification (HO) because of the more permissive environment of damaged muscle and the inability of BMP inhibitors in the tissue to alter the osteogenic program of multipotent progenitor cells.

occurred. This might be because noggin, an effective antagonist of BMP-2 and BMP-7, cannot inhibit BMP-9 $[29,30]$ (Figure 4).

The difference in BMP expression in healing fractures and in $\mathrm{HO}$ might also be explained by the nature of the cells involved. A number of studies using animal models [9,31] and human cells [32] have shown that muscle resident stromal cells ( $\mathrm{mrSCs}$ ) with high osteogenic potential contribute to HO. This finding has important clinical implications since mrSCs may be involved in fracture repair [33-35]. More importantly, non-unions are more likely to be associated with bones with minimal soft tissue coverage such as the tibia, and it has been proposed that non-unions could occur due to the lack of enveloping muscle tissue [36]. The present case report underlines the importance of concentrating future studies on identifying the true role of multipotent mrSCs and the pathway leading to their osteogenic commitment.

\section{Conclusions}

We showed that BMPs are expressed in traumatic $\mathrm{HO}$ and that BMP-9 in particular may play a pivotal role in $\mathrm{HO}$ because of the more permissive environment of damaged muscle and the inability of BMP inhibitors in the microenvironment to alter the osteogenic program of multipotent progenitor cells. We propose that osteogenic multipotent progenitor cells, including mrSCs, and their signaling pathways should be investigated further with a view to developing prophylactic measures to prevent traumatic $\mathrm{HO}$.

\section{Consent}

Informed consent was obtained from the patient for the publication of this case report and any accompanying images.

\section{Abbreviations \\ AD: adipocyte; AP: antero-posterior; BMP: bone morphogenetic protein; BM: bone marrow; BV: blood vessel; $\mathrm{CH}$ : chondrocytes; $\mathrm{CT}$ : computerized tomography; EC: endothelial cell; FB: fibroblasts; HO: heterotopic ossification; MC: mesenchymal cells; MF: myofiber; mrSC: muscle resident stromal cell; NSAIDs: non-steroidal anti-inflammatory drugs; OB: osteoblasts; ORIF: open reduction and internal fixation; TGF- $\beta$ : transforming growth factor-beta.}

\section{Competing interests}

The authors declare that they have no competing interests.

\section{Authors' contributions}

Collecting the data: DL and PK. Analyzing the data: GG, EL, NF, PK and RH. Interpreting the data: GG, EL, NF, PK and RH. Drafting the manuscript: GG, EL and NF. Approving the final version of the manuscript: GG, EL, DL, NF, PK and $\mathrm{RH}$. GG, EL, DL, NF, PK, and $\mathrm{RH}$ are responsible for the integrity of the data analysis. All authors read and approved the final manuscript.

\section{Acknowledgments}

We are grateful to Dr. Amy Svotelis for her critical reading of the manuscript. GG and RH received investigator awards from Fonds de Recherche Québec en Santé (FRQS). GG, NF, and RH hold grants from the Canadian Institutes of Health Research (CIHR).

\section{Author details}

'Étienne-Le Bel Clinical Research Centre, Sherbrooke, QC, Canada. 2Department of Orthopedic Surgery, Faculty of Medicine, Université de Sherbrooke, Sherbrooke, QC, Canada. ${ }^{3}$ Shriners Hospital for Children, 1529 Cedar Avenue, Montreal, QC H3G 1A6, Canada. ${ }^{4}$ Department of Surgery, Orthopedic Surgery Division, McGill University, Montreal, QC, Canada. ${ }^{5}$ Department of Chemical and Biotechnological Engineering, Faculty of Engineering, Université de Sherbrooke, Sherbrooke, QC, Canada. ${ }^{6}$ Department of Orthopedic Surgery, Academic Medical Center, Amsterdam, Netherlands. 
Received: 6 October 2013 Accepted: 20 November 2013

Published: 16 December 2013

\section{References}

1. Nauth A, Giles E, Potter BK, Nesti LJ, O'Brien FP, Bosse MJ, Anglen JO, Mehta $\mathrm{S}$, Ahn J, Miclau T, et al: Heterotopic ossification in orthopedic trauma. J Orthop Trauma 2012, 26(12):684-688.

2. Chalmers J, Gray DH, Rush J: Observations on the induction of bone in soft tissues. J Bone Joint Surg Br 1975, 57(1):36-45.

3. Baird EO, Kang QK: Prophylaxis of heterotopic ossification - an updated review. J Orthop Surg Res 2009, 4:12.

4. Nishimura R, Hata K, Matsubara T, Wakabayashi M, Yoneda T: Regulation of bone and cartilage development by network between BMP signaling and transcription factors. J Biochem 2012, 151(3):247-254.

5. Chen G, Deng C, Li YP: TGF-beta and BMP signaling in osteoblast differentiation and bone formation. Int J Bio/ Sci 2012, 8(2):272-288.

6. Bragdon B, Moseychuk O, Saldanha S, King D, Julian J, Nohe A: Bone morphogenetic proteins: a critical review. Cell Signal 2011, 23(4):609-620.

7. Kang $Q$, Sun MH, Cheng H, Peng Y, Montag AG, Deyrup AT, Jiang W, Luu $\mathrm{HH}$, Luo J, Szatkowski JP, et al: Characterization of the distinct orthotopic bone-forming activity of 14 BMPs using recombinant adenovirusmediated gene delivery. Gene Ther 2004, 11(17):1312-1320.

8. Li JZ, Li H, Sasaki T, Holman D, Beres B, Dumont RJ, Pittman DD, Hankins GR, Helm GA: Osteogenic potential of five different recombinant human bone morphogenetic protein adenoviral vectors in the rat. Gene Ther 2003, 10(20):1735-1743.

9. Leblanc E, Trensz F, Haroun S, Drouin G, Bergeron E, Penton CM, Montanaro F, Roux S, Faucheux N, Grenier G: BMP-9-induced muscle heterotopic ossification requires changes to the skeletal muscle microenvironment. J Bone Miner Res 2011, 26(6):1166-1177.

10. Bidart M, Ricard N, Levet S, Samson M, Mallet C, David L, Subileau M, Tillet E, Feige JJ, Bailly S: BMP9 is produced by hepatocytes and circulates mainly in an active mature form complexed to its prodomain. Cell Mol Life Sci 2012, 69(2):313-324.

11. Tsialogiannis E, Polyzois I, Oak Tang Q, Pavlou G, Tsiridis E, Heliotis M: Targeting bone morphogenetic protein antagonists: in vitro and in vivo evidence of their role in bone metabolism. Expert Opin Ther Targets 2009, 13(1):123-137.

12. ten Dijke $\mathrm{P}$, Miyazono $\mathrm{K}$, Heldin $\mathrm{CH}$ : Signaling inputs converge on nuclear effectors in TGF-beta signaling. Trends Biochem Sci 2000, 25(2):64-70.

13. Kloen P, Di Paola M, Borens O, Richmond J, Perino G, Helfet DL, Goumans MJ: BMP signaling components are expressed in human fracture callus. Bone 2003, 33(3):362-371.

14. Kloen P, Doty SB, Gordon E, Rubel IF, Goumans MJ, Helfet DL: Expression and activation of the BMP-signaling components in human fracture nonunions. J Bone Joint Surg Am 2002, 84-A(11):1909-1918.

15. Kloen P, Lauzier D, Hamdy RC: Co-expression of BMPs and BMP-inhibitors in human fractures and non-unions. Bone 2012, 51(1):59-68.

16. Kwong FN, Hoyland JA, Evans CH, Freemont AJ: Regional and cellular localization of BMPs and their inhibitors' expression in human fractures. Int Orthop 2009, 33(1):281-288.

17. Fajardo M, Liu CJ, Egol K: Levels of expression for BMP-7 and several BMP antagonists may play an integral role in a fracture nonunion: a pilot study. Clin Orthop Relat Res 2009, 467(12):3071-3078.

18. Siebenrock KA, Gautier E, Ziran BH, Ganz R: Trochanteric flip osteotomy for cranial extension and muscle protection in acetabular fracture fixation using a Kocher-Langenbeck approach. J Orthop Trauma 2006, 20(Suppl 1):S52-S56.

19. Guerado E, Cano JR, Cruz E: Simultaneous ilioinguinal and KocherLangenbeck approaches for the treatment of complex acetabular fractures. Hip Int 2010, 20(Suppl 7):S2-S10.

20. Campisi P, Hamdy RC, Lauzier D, Amako M, Rauch F, Lessard ML: Expression of bone morphogenetic proteins during mandibular distraction osteogenesis. Plast Reconstr Surg 2003, 111(1):201-208. discussion 209-210.

21. Rauch F, Lauzier D, Croteau S, Travers R, Glorieux FH, Hamdy R: Temporal and spatial expression of bone morphogenetic protein-2, -4 , and -7 during distraction osteogenesis in rabbits. Bone 2000, 27(3):453-459.

22. Hamdy RC, Amako M, Beckman L, Kawaguchi M, Rauch F, Lauzier D, Steffen $\mathrm{T}$ : Effects of osteogenic protein-1 on distraction osteogenesis in rabbits. Bone 2003, 33(2):248-255.
23. Haque T, Hamade F, Alam N, Kotsiopriftis M, Lauzier D, St-Arnaud R, Hamdy $\mathrm{RC}$ : Characterizing the BMP pathway in a wild type mouse model of distraction osteogenesis. Bone 2008, 42(6):1144-1153.

24. Haque T, Mandu-Hrit M, Rauch F, Lauzier D, Tabrizian M, Hamdy RC: Immunohistochemical localization of bone morphogenetic proteinsignaling Smads during long-bone distraction osteogenesis. $J$ Histochem Cytochem 2006, 54(4):407-415.

25. Warren SB, Brooker AF Jr: Intramedullary nailing of tibial nonunions. Clin Orthop Relat Res 1992, 285:236-243.

26. Davis TA, Lazdun Y, Potter BK, Forsberg JA: Ectopic bone formation in severely combat-injured orthopedic patients - a hematopoietic niche. Bone 2013, 56(1):119-126.

27. Shore EM: Osteoinductive signals and heterotopic ossification. J Bone Miner Res 2011, 26(6):1163-1165.

28. David L, Mallet C, Keramidas M, Lamande N, Gasc JM, Dupuis-Girod S, Plauchu H, Feige JJ, Bailly S: Bone morphogenetic protein-9 is a circulating vascular quiescence factor. Circ Res 2008, 102(8):914-922.

29. Bergeron E, Senta H, Mailloux A, Park H, Lord E, Faucheux N: Murine preosteoblast differentiation induced by a peptide derived from bone morphogenetic proteins-9. Tissue Eng Part A 2009, 15(11):3341-3349.

30. Wang Y, Hong S, Li M, Zhang J, Bi Y, He Y, Liu X, Nan G, Su Y, Zhu G, et al: Noggin resistance contributes to the potent osteogenic capability of BMP9 in mesenchymal stem cells. J Orthop Res 2013, 31(11):1796-1803.

31. Wosczyna MN, Biswas AA, Cogswell CA, Goldhamer DJ: Multipotent progenitors resident in the skeletal muscle interstitium exhibit robust BMP-dependent osteogenic activity and mediate heterotopic ossification. J Bone Miner Res 2012, 27(5):1004-1017.

32. Davis TA, O'Brien FP, Anam K, Grijalva S, Potter BK, Elster EA: Heterotopic ossification in complex orthopedic combat wounds: quantification and characterization of osteogenic precursor cell activity in traumatized muscle. J Bone Joint Surg Am 2011, 93(12):1122-1131.

33. Gates CB, Karthikeyan T, Fu F, Huard J: Regenerative medicine for the musculoskeletal system based on muscle-derived stem cells. J Am Acad Orthop Surg 2008, 16(2):68-76.

34. Liu R, Schindeler A, Little DG: The potential role of muscle in bone repair. J Musculoskelet Neuronal Interact 2010, 10(1):71-76.

35. Schindeler A, Liu R, Little DG: The contribution of different cell lineages to bone repair: exploring a role for muscle stem cells. Differentiation 2009, 77(1):12-18.

36. Audige L, Griffin D, Bhandari M, Kellam J, Ruedi TP: Path analysis of factors for delayed healing and nonunion in 416 operatively treated tibial shaft fractures. Clin Orthop Relat Res 2005, 438:221-232.

doi:10.1186/2044-5040-3-29

Cite this article as: Grenier et al.: BMP-9 expression in human traumatic heterotopic ossification: a case report. Skeletal Muscle 2013 3:29.

\section{Submit your next manuscript to BioMed Central and take full advantage of:}

- Convenient online submission

- Thorough peer review

- No space constraints or color figure charges

- Immediate publication on acceptance

- Inclusion in PubMed, CAS, Scopus and Google Scholar

- Research which is freely available for redistribution 